\section{Anticipation or not?}

\author{
The Origin of Species Revisited. A Victorian \\ who Anticipated Modern Developments in \\ Darwin's Theory \\ DR Forsdyke \\ McGill-Queen's University Press, Kingston and Montreal. 2001; \\ 275 pp. £37.95, hardcover. ISBN 0-7735-2259-X
}

Heredity (2003) 90, 416-417. doi:10.1038/sj.hdy.6800233

\section{Reviewed by DM Porter}

This book is not really about Darwin, or The Origin of Species, although they are mentioned. It is mostly about George Romanes, William Bateson, and Donald Forsdyke. The book is presented in four parts. The first part (Search for a Victorian) 'considers the difficulties the Victorians had with Darwin's theory' and Forsdyke's 'search for an unrecognized Victorian who might have solved them' ( $p$ 2). The former is well documented here and elsewhere, especially Darwin's search to understand how morphological characters are inherited. The chapters in Part 1 are mainly given over to discussions of aspects of Darwin's difficulties, using quotations from the publications of Romanes, Bateson, and their contemporaries in an attempt to explain his difficulties, but in a nonDarwinian way. For example, Forsdyke writes favorably about group selection, 'anathema to some evolutionists' ( $\mathrm{p}$ 38; emphasis mine), an interesting idea for which no empirical data exist. He also separates reproductive isolation (or 'reproductive selection', leading to 'polytypic (divergent) evolution') from natural selection (or 'phenotypic selection', leading to 'monotypic (nonbranching) evolution') without mentioning that the two are inseparable in modem evolutionary theory. Indeed, in looking at the book's bibliography, the reader would not know that Theodosius Dobzhansky had published anything after 1937, GL Stebbins after 1981, or Ernst Mayr after 1982.

For unrecognized Victorians, Forsdyke comes up with Romanes (1848-1894) and Bateson (1861-1926), who are painted as outsiders, oppressed by the biological establishment. Yet both became Fellows of the Royal Society. Romanes, a pioneer investigator in the fields of invertebrate physiology, comparative psychology, and animal behavior, studied at Cambridge and University College London. Like Darwin, he was independently wealthy and able to devote himself to scientific research. Romanes was twice Croonian Lecturer, Rede Lecturer, zoological secretary of the Linnean Society, member of the council of UCL, honorary fellow of Gonville \& Caius College, honorary LLD, Aberdeen, and had a lectureship named for him at Oxford during his lifetime. Had he lived longer, he might have equalled Bateson in awards. Bateson was the founder of the experimental study of heredity and variation, and one of the rediscoverers of Mendel's experiments. Unlike Darwin and Romanes, he was not independently wealthy and chose to work in academia. He also was trained at Cambridge, became a fellow of St John's College, then reader in zoology, professor of genetics (the professorship was founded for him), and first director of the John Innes Horticultural Institute. Bateson was awarded the Darwin and Royal medals of the Royal Society, was president of the British Association for the Advancement of Science, Silliman Lecturer at Yale, Herbert Spencer Lecturer at Oxford, and elected a trustee of the British Museum. While it is true that Romanes was criticized for his acceptance of the inheritance of acquired characteristics (which Darwin also accepted) and his hypothesis of physiological selection (he argued that natural selection does not effect all variation), and Bateson did not accept the theory of evolution by natural selection, neither were outside of the Victorian biological establishment.

In the second part (The species-dependent component of base composition), Forsdyke argues that 'the chemical basis of the origin of species by 'physiological selection' is something biochemists have known about for many decades'; that is, 'the speciesdependent component of the base composition of DNA. This is the 'holy grail' sought by Romanes and Bateson.' ( $p$ 2). This is also the toughest part of the book to understand; it requires a knowledge of molecular biology that the ordinary reader at which the book appears to be pitched probably will not have. It is also difficult to follow logically, with its continual 'if this might have happened, then maybe this also happened'.

As a result of the ratio of the DNA bases guanine and cytosine $(\mathrm{G}+\mathrm{C})$ to the total bases, these plus adenine and thymine $(A+C+G+T)$, appearing to be constant in virus and bacteria species, Forsdyke concludes that $(\mathrm{C}+\mathrm{G}) \%$ is 'an important species characteristic' and ' $(\mathrm{G}+\mathrm{C}) \%$ differences can correlate with phylogenetic differences' (pp 102-104). In addition, 'compatibility in $(\mathrm{C}+\mathrm{G})$ percentages is required for recombination between DNA molecules' ( $p$ 133). So differences in G+C ratios of genetically similar individuals can play a role in the hybrid sterility that leads to speciation. Random fluctuations in a species' ratio may lead to sympatric speciation, and further differentiation 'into higher taxonomic groupings will occur through further speciation events and conventional Darwinian natural selection' ( $p$ 133). Forsdyke postulates that this speciesdependent $\mathrm{G}+\mathrm{C}$ component of DNA base composition in meiotically pairing chromosomes is the modern chemical equivalent' of Darwin's 'other and unknown changes', Romanes' 'physiological components', and Bateson's 'complementary factors'. Experiments have shown that $\mathrm{G}+\mathrm{C}$ content can relate to the thermal stability of double-stranded DNA, generally the more $\mathrm{G}+\mathrm{C}$, the more stable; but nothing more. Needless to say, Forsdyke's 'Physiological Selection Theory' is a controversial one (see Kliman RM, et al (2001). J Theor Biol 209: 131-140).

In the third part (The divergence and convergence of species), 'some outstanding problems in biology and medicine' are considered 'from this new perspective' 
(p 2). Here, junk DNA, viral latency, altruism, replicators, sequence space, RNA and DNA, introns, and other subjects are discussed in terms of 'conflicts between the apparent agendas of genes, individuals, and groups of individuals' ( $p$ 148). The initiation of speciation is the beginning of the much slower process of adaptive fine-tuning. Secondary adaptations are viewed as being continuously fine-tuned, which bears on interactions with viruses and other pathogens. This section concludes with discussions of genetic dominance and sex chromosomes. Throughout, phenomena are interpreted in terms of Forsdyke's 'Physiological Selection Theory'.

The fourth part (The Darwinian struggle for truth) asks the question, since Romanes has provided such a clearly described foundation for Forsdyke's studies, 'why has it had such little impact?' (p 204). After all, Romanes was Darwin's last protégé, although not the 'youth' described ( $p$ 206) who first met Darwin in 1874. Romanes was then 26 (Darwin was 22 when he went off on the Beagle). These chapters primarily deal with the attacks on Romanes' evolutionary ideas by Alfred Russel Wallace, W. T. Thistleton-Dyer, E. Ray Lankester, and Thomas Henry Huxley. Forsdyke feels that Romanes' untimely death in 1894 robbed him of the opportunity to develop fully and defend these ideas. 'So successful were the efforts of Huxley, Wallace and their supporters, that Romanes himself has been consigned to relative obscurity' ( $p$ 228). In the 20th century, those researchers who believed that hybrid sterility had a genic basis won out over those who believed it to have a chromosomal basis. That is, until Forsdyke came along and tied his ideas to those of Romanes and Bateson.

The last two chapters discuss the problems that Romanes and Bateson had with their peers accepting their ideas. Forsdyke not so subtly hints that he has the same problems: 'The dynamics of peer-resistance to novel ideas in the Victorian era may be similar to those of the present era' ( $p$ 233). About the same time that this book was published, a series of review articles on speciation appeared in a special issue of Trends in Ecology $\mathcal{E}$ Evolution ((2001) 16: 325-413). None of the articles cite Forsdyke's research.

Neither historians of science, geneticists, molecular biologists, nor systematists may like this book, but they should read it. I have long believed that you can learn a great deal about your field by reading a publication with which you do not agree. It helps you to hone your arguments, and, if it makes you think, it was worth reading.

It is unfortunate that the publisher has chosen a title that is the same as that of a notoriously antievolution screed by Wendell R. Bird, originally published in 1989 and reprinted several times since. Although Bird's book is subtitled 'The theories of evolution and of abrupt appearance', they still may be confused.

DM Porter

Department of Biology, Virginia Polytechnic Institute E State University, Blacksburg, VA 24061, USA. E-mail: duporter@vt.edu 